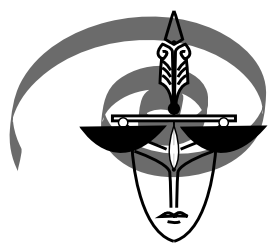

EUROPEAN

Volume $11 \cdot 2017 \cdot$ Number $4(42)$

DOI: 10.1515/ep-2017-0017

Łukasz Lep*

\title{
Polygraph Examinations in the Secret Services of the People's Republic of Poland
}

Использование полиграфных исследований спецслужбами Польской Народной Республики

Key words: polygraph in Polish People Republic, polygraph in Poland, polygraph in comunists countries

In the days of the Warsaw Pact, Poland, at the time officially and constitutionally the People's Republic of Poland, diverged from other members of the Warsaw Pact. Poland had individual farms throughout the time, and after 1956 the Catholic Church operated in principle without obstacles, culture developed basically without hindrance despite the official censorship, and the communist regime itself was not as oppressive as in the other states of the Eastern Bloc. The role of intelligence and counterintelligence agencies in the structure of organs of the state, as well as their organisation and competences, were, however, fundamentally similar to those in the other states of the bloc, dependent on the USSR.

Until 1990, the Polish secret services operated in the following ministries: the Ministry of Internal Affairs (civilian intelligence and counterintelligence, political police) and the Ministry of National Defence (military intelligence and counterintelligence). After

*lukas87@gmail.com 
numerous reorganizations after 1956, in the 1970s, and in the 1980s, the following civilian secret services reported to the Minister of Internal Affairs [1]

- Department I of the Ministry of Internal Affairs (civilian political and economicintelligence),

- Department II of the Ministry of Internal Affairs (civilian counterintelligence), and

- Departments III-VI of the Ministry of Internal Affairs (Stużba Bezpieczeństwa: political police). In addition to the departments at the central level, there were also offices "A" (codes), "B" (observation), "C" (files, and records of investigation), "T" (investigation techniques), "W" (control of correspondence), and the Government Protection Bureau [2]

At the same time, intelligence agencies reporting to the Minister of National Defence included:

- Section II of the Polish General Staff (military intelligence; the Board of the Second General Staff of the Polish Army)

- Military Internal Service (WSW, military counterintelligence and military police, including military political police).

The structures of the Ministry of the Interior also included state police forces operating under the name of Milicja Obywatelska (literally: "citizen militia").

The Department II of the Ministry of the Interior, the Security Service, the Board of the Second General Staff of the Polish Army, and the Military Internal Service of the Ministry of National Defence operated until the adoption of a number of acts including those of 6 April 1990 on the Ministry of the Interior, [3] Police, [4] and National Office for State Protection, [5], when they were terminated.

\section{The first polygraph examinations in Poland}

It was still before the Second World War that the Polish State Institute of Psychological Hygiene purchased an American polygraph (Darrow's photo polygraph), [6] which was nonetheless only applied for investigating emotions, and was used neither for practical nor experimental studies of lie detection. [7] The device was lost when Poland fell under Nazi occupation during the war. Moreover, also before the Second World War, Polish expert literature published information on the use of polygraph in the US [8] and the experimental studies E. Seelig conducted in Germany. [9]

After 1945, polygraph received only bad press in Poland, as it was perceived "an imperialistic tool" that served "the aggravation of the atmosphere of intimidation" during 
interrogations. This is how a polygraph examination was described in the first Polish criminalistics course book written by Paweł Horoszowski. [10]

Early in the 1960s, while on a Ford Foundation scholarship to the US, the same Paweł Horoszowski purchased a three-channel Stoelting polygraph (model \#22500) and brought it to Poland. It was the first polygraph, considered modern at the time, that found its way to Poland. Horoszowski underwent no specialist training, nor did he publish any experimental works on polygraph examinations, yet he embarked on running such examinations to provide evidence in criminal cases. He performed first such examination on 27 June 1963 in a manslaughter case before the Regional Prosecutor's Office in Olsztyn (file II Ds. 25/63). He repeated such an examination in another criminal case in 1964; this one was investigated by the Regional Court in Lublin (file IV K 27/64). The cases were extensively discussed in both contemporary and later literature. [12]

They resulted in the first ruling of the Supreme Court on the admissibility of polygraph examinations in criminal cases (file III K 177/64). The statement, however, was fairly enigmatic [13] and subject to different interpretations, yet it remains incontrovertible that the Supreme Court did not explicitly forbid the use of such examinations in criminal cases. [14] These first attempts at using polygraph for criminal procedures resulted in broad discussion continued both in legal and forensic magazines. [15] The discussion intensified the popularity of this form of examination, and general attention was turned to issues of legal, psychological, and criminal science nature connected to sanctioning such examinations in trials. This, in turn, encouraged both legal considerations and running experimental works that among others tested the diagnostic value of such an examination. [16]

One can remark that the range of issues typical of polygraph examinations was quite well known to scientific circles, both legal and forensic, in Poland of the late 1960s and early 1970s. [17]

\section{The first information of secret services of the Polish People's Republic on polygraph tests}

Information on the possibilities of using the polygraph for the needs of secret services first arrived in Poland after the Second World War. Already in 1945 the Polish intelligence knew that the Americans used polygraph tests to interrogate German and Japanese prisoners. [18] 
Already in the 1950s, interrogations of captured American spies let the intelligence and counterintelligence services of the People's Republic of Poland learn that they had been trained in intelligence centres before being sent to Poland, and there they had been examined with the use of polygraphs.

Relevant information, gathered by counterintelligence interrogating US intelligence agents captured in Poland, corroborated by the intelligence gathered in the field in the US gave a more and more detailed picture of the use of polygraph in US intelligence services. [19]

The example of W.S. working in a prisoner of war camp in Germany from 1939 to 1948 shows what loyalty tests American intelligence used on candidates for agents. [20]

Intelligence became interested in W.S. as soon as he started service in American guard companies. In 1951 he was sent from Munich for "verification tests" in an intelligence centre, where he was subjected to polygraph examinations. Such an examination was the last stage of testing the candidate's suitability to work for the intelligence. With a positive result of the examination, W.S. was taken to an American base for nine months. In this time he underwent an intensified training in diversion and espionage. [21]

From 1951 to 1955, US intelligence transported intelligence agents to Poland by submarines and aircraft. The capture of two US spies parachuted in 1952 around Koszalin [22] was a significant impulse to take interest in polygraph tests in favour of also using them by secret service of the Polish People's Republic. [23]

Personal sources of intelligence services were polygraph tested from time to time [24] to verify the credibility of their reports, to make sure whether the agents were not rerecruited while staying abroad, and to asses general agent loyalty. [25] Negative test results made the CIA discontinue cooperation with the given agent. In the days of the People's Republic, Polish Security Service was furthermore in possession of information that the American intelligence and counterintelligence agencies were as yet the only ones to use polygraph examinations on their personal sources of information routinely. At this time, Americans considered polygraph examination the last step in their validation of a specific person before embarking on cooperation. [26]

The explanations of people accused of espionage suggest that Americans were in favour of determining whether the examinees are employed or secretly collaborate with Polish intelligence and counterintelligence agencies. If only possible, such people were subjected to regular controls. The successive examinations were to discover whether the subject had not started cooperation with the Polish Security Service from the time of the previous examination, assess his loyalty, and explain certain potential details from his life. [27] 
Polygraph examinations were conducted according to the Reid's Control Questions Technique with elements of Baxter's or Ferguson's technique.

The analysis of explanations shows that the Lafayette model 762-95 GA may have been used in some cases. [28] At that time, it was a new generation device.

An investigation of the explanations provided by American agents captured in Poland indicated that Lafayette polygraphs were probably used in some cases. At the time they were a new generation device. As American intelligence and counterintelligence agencies found results of polygraph examinations especially significant, Polish services had to gather all information on the subject in a continuous and coordinated manner. Polygraph experts working in Polish intelligence and counterintelligence agencies participated in these sections of interrogations of captured American agents that concerned the polygraph procedures that those agents had been subjected to before being sent to Poland. Their task was to verify the veracity of this part of evidence and to update their knowledge of polygraph examinations performed by American services, which also meant gaining information about innovation in this area. With appropriate aids, including catalogues, experts could reconstruct the course of polygraph examination in greater detail, together with the accompanying circumstances, and also fine-tune information concerning the type of device used and the examination itself. [29]

Moreover, descriptions of testing soldier behaviour during the Second World War were also known from the collection of books The American Soldier. Combat and its Aftermath, translated into Polish, edited by Jerzy Wiatr, and published by the Main Political Board of the Polish Army only in 1960. The publication was secret and the Polish translation was only available to Polish Army generals and officers. It also included information on polygraph examinations performed by American services during the Second World War and immediately after it.

Such information was complementary with that published in scientific and expert literature after Paweł Horoszowski brought the first polygraph to Poland and employed it in criminal procedures for the first time in Poland. [30]

\section{Polygraph tests carried out by secret services of the People's Republic of Poland}

This resulted in a decision to purchase a polygraph for the Military Internal Service(WSW) in the second half of the 1960s. A three-channel Keeler Polygraph (model 6308), [31] was purchased for the needs of the services. It functioned for 12 years, when equipment of a later generation was purchased (Stoelting and Lafaytte 
polygraphs) [32]. Obtaining one was not easy however. Late in the 1970s American companies did not sell polygraphs to the states "beyond the Iron Curtain". Even access to literature was made difficult. As late as in 1976 American Polygraph Association refused a Polish subscription of Polygraph quarterly, explaining straightforwardly that "publications of the American Polygraph Association are not sent beyond the Iron Curtain". The first machine for the Military Internal Service, was a Keeler Polygraph (model \# 6306), which was purchased through intelligence channels in 1969. [33]

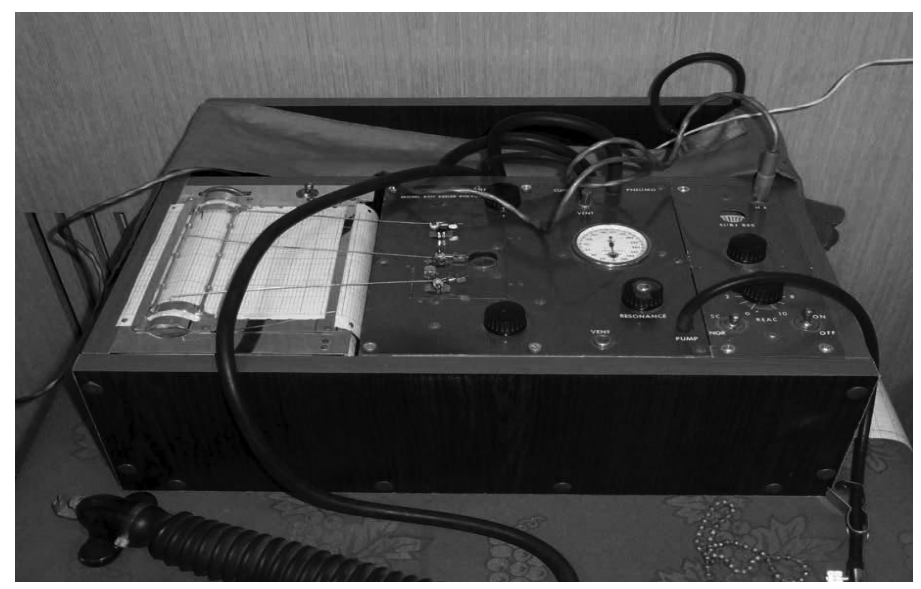

Fig. 1. Keeler Polygraph, model 6306, used since the late 1960s by the Military Internal Service (now in the collection of the Military Police).

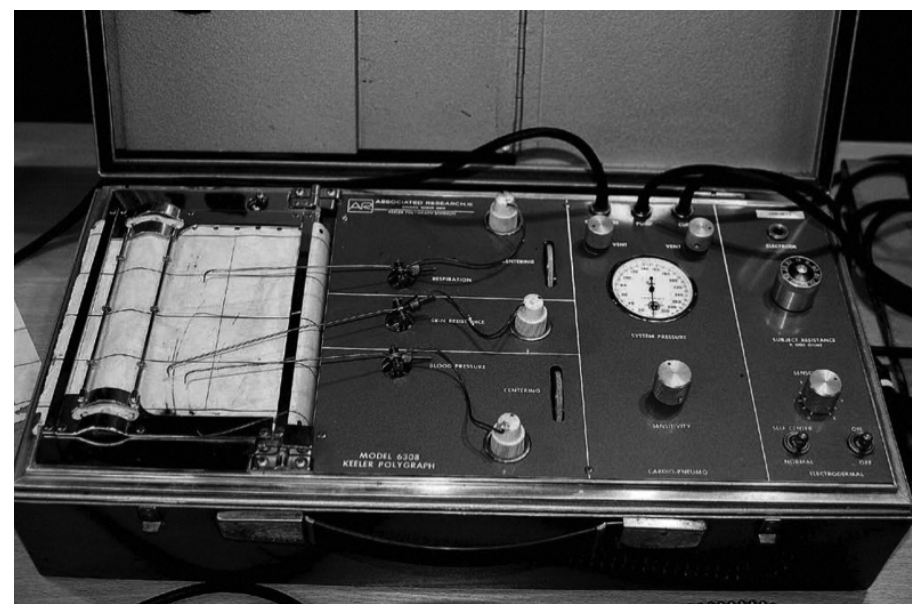

Fig. 2. Keeler Polygraph, model 6308, used since the early 1970s by the Ministry of the Interior (currently in the collection of the Central Training Centre of the Internal Security Agency in Emów). 
Somewhat later, a similar method was relied on to purchase a more modern machine, a Keeler Polygraph (model \#6308) for the needs of intelligence and counterintelligence of the Ministry of Internal Affairs. [34]

The Military Internal Service (WSW) conducted psychophysiological tests with the use of polygraph in a specific environment, which was an advantage. The Reid technique was most often used for the tests experts from these services performed. [35] Altogether, military experts examined 4,626 people in 943 cases in 1969-1989. [36] Literature shows that the Military Internal Service experts in polygraph testing examined 1,590 people in 274 cases in 1969-1976. This marked a rising trend in polygraph testing is visible. The number of subjects of polygraph examinations in 1969 was 85 in four cases. In 1976, 304 people were examined in 54 cases. In that period most cases concerned the misappropriation of firearms (92), followed by assassinations (76), misappropriation of military property (26), loss of classified documents (19), robbery (5), rape (2), and fire (1). [37]

In the eight years from 1969 to 1976 the Military Internal Service carried out 1,590 tests in 274 cases. They were conducted by various operational units of the Military Internal Service at the level of district authorities (in the Pomeranian, Silesian, and Warsaw military districts) and Polish Armed Forces (Polish Navy, Air Force, and Aerial Defence). It is worth noting that only one procedure was carried out for the needs of the military prosecutor's office. The examinations of the remaining 1,589 people were probably carried by specialised units for investigative and intelligence purposes. [38]

Interestingly, at that time, the executives at the Ministry of the Internal Affairs opposed the use of polygraph examinations for criminal procedures and the control its officers. [39] They were only used for investigation and intelligence procedures, including training of own agents before sending them abroad, as well as for interrogating foreign intelligence agents captured in Poland. For example, a polygraph examination was approved in acriminal case of espionage investigated by the Regional Military Court in Bydgoszcz (file SO 72/69). [40] Such examinations were also conducted after various investigation centres had gathered information about a candidate.

In 1970-1984, the Investigations Centre of the Ministry of Internal Affairs conducted 27 investigations on the power of Art. 124 of the Criminal Code (espionage) on suspected Polish citizens. Polygraph examinations were administered in five cases including six suspects. Polygraph examinations became a necessary element for intelligence and counterintelligence services to obtain information about people staying within the realm of their interest, as well as for the selection and control of people working in the services. Such examinations were also used to control the agents recruited for cooperation. [41] 
Besides the uses of polygraph described above, experts of the Polish Military Internal Service used them in criminal cases conducted by the offices of military prosecutors, most of which concerned the loss or theft of weapons. [42] Such cases shared certain specific traits, as there was usually a closed circle of suspects (a small sub-unit, such as a squad or platoon), which quite naturally favoured the success of the investigation. Since the 1970s, Military Internal Service polygraphers have also been appointed as experts and have carried out polygraph tests in criminal cases conducted by General (Civil) Prosecutor's Offices and concerning the gravest crimes, usually murders. In 1970-1976, they carried out polygraph tests in 223 criminal cases, most of which were murder cases. [43] In 1969-89, military experts examined 4,626 people in 943 cases. [44]

In 1970-1975 the Citizens' Militia (Milicja Obywatelska, MO, Polish police force) used polygraph tests on 193 subjects as part of 59 cases. [45] The all concerned the gravest crimes. In the second half of the 1970s, polygraph examinations in criminal cases again began to be performed in Poland also by expert university staff. [46] The number of the procedures they administered was greater than that conducted in such cases by intelligence and counterintelligence experts.

One of the subjects examined by the Military Internal Service experts was Zdzisław Marchwicki, suspected of being a sex-motivated serial killer and popularly dubbed the region's "vampire". [47]

It should be added that the Supreme Court unambiguously recognised polygraph examinations permissible in a criminal trial, yet only "in ancillary character" in a sentence of 25 September 1976 (file: II KR 171/76), and decided that they "cannot pose an independent proof giving foundation for specific decisions". [48]

A serious lack of professional recognition for experts, which doctors and lawyers enjoyed, was characteristic of the time of People's Republic of Poland. [49]

Initially, the use of the polygraph followed emotional rather than substantive arguments. Such a position was also influenced by popular press 50 and available literature, which in a way developed people's awareness. [51] In his short story Electronic Subversive Ideas Detector Stanisław Lem created a caricature representation of a machine known as Electronic Subversive Ideas Detector that was in the services of the "capitalist police" and was meant "to reveal people with communist views" and examine their loyalty. [52]

It is interesting and in fact difficult to explain why, while conducting criminal investigations, the MO police force only used the Military Internal Service(and later also university) experts and neither purchased a polygraph nor trained its own experts. 
The situation changed radically after the systemic change of 1990, yet this already lies beyond the scope of this paper. Recapitulating, one needs to reiterate that Poland differed from the other countries of the Warsaw Bloc also in the application of polygraph examinations as no polygraph tests were carried out in most countries of the bloc from 1970 to 1990: in the USSR, the KGB only became interested in the polygraph in 1975, [53] and only experimental tests were done in Czechoslovakia. [54] Besides Poland, polygraph tests were applied in practice only in Yugoslavia. [55]

Concluding, it must be stated that even in the options of polygraph test use, Poland differed from the remaining countries of the Communist Bloc.

\section{References}

1. Stużba Bezpieczeństwa w Polskiej Rzeczpospolitej Ludowej w latach 1944-1978. Centrala, vols 1-2, pp. 216-218, Warszawa 1978. The compendium was published by Mirosław Piotrowski as Ludzie bezpieki w walce z Narodem i Kościotem, Lublin 1999.

2. J. Widacki, Czego niepowiedziat generat Kiszczak, Warszawa 1992, p. 14; the scope of activity of highest ranking officials in the Ministry of Internal Affairs was set in Resolution of the Minister of Internal Affairs No. 051/85 of 18 July 1985 and the Resolution No. 041/89 of 11 May 1989 amending it.

3. Act of 6 April 1990 on the on the office of the Minister of the Interior, Journal of Laws, 1990, No. 30, item 181.

4. Act of 6 April 1990 on Police, Journal of Laws, No. 30, item 179.

5. Act of 6 April 1990 on the National Office for State Protection, Journal of Laws, No. 30, item 180.

6. A. Krzyścin, Zastosowanie poligrafu (wariografu) w sprawach kryminalnych w świetle doświadczeń amerykańskich organów ścigania, Zeszyty Naukowe Wyższej Szkoły Oficerskiej MSW w Szczytnie 1978, special issue, No. 7, p. 123; M. Kulicki, S. Koebcke, Wariograficzna rejestracja zmian emocjonalnych, [in:] Zeszyt Naukowy Wyższej Szkoły Oficerskiej, Szczytno, January-March 1976, No. 12, p. 55.

7. J. Widacki, Wprowadzenie do problematyki badań poligraficznych, Warszawa 1981, p. 181.

8. R.O. Arther, The Scientific Investigator, 2nd ed., Illinois US, 1970, pp. 26-38.

9. A. Krzyścin, Rozwój kryminalistycznych badań poligraficznych w latach 1920-1995, Problemy Kryminalistyki 1995, No. 209, pp. 21-23. 
10. See: P. Horoszowski, Kryminalistyka, PWN, Warszawa 1958, pp. 125-128.

11. M. Kulicki (ed.), Kryminalistyka wybrane zagadnienia teorii i praktyki śledczo-sądo$w e j$, Toruń 2005, p. 611.

12. J. Widacki, Analiza przestanek diagnostycznych $w$ badaniach poligraficznych, Katowice 1982, p. 7, 16 and ff.; see: Badania poligraficzne w Polsce, ed. by J. Widacki, OficynaWydawnicza AFM, Kraków 2014, p. 35.

13. Ruling of the Supreme Court of 1964, III K 177/64.

14. See: Badania poligraficzne w Polsce, ed. by J. Widacki, Oficyna Wydawnicza AFM, Kraków 2014, p. 39.

15. See: J. Widacki, Badania poligraficzne w Polsce, ed. by J. Widacki, Oficyna Wydawnicza AFM, Kraków 2014, pp. 31-50; see: L. Gardocki, II Międzynarodowe Sympozjum Prawa Karnego Państw Socjalistycznych, Państwo i Prawo, No. 3,1978, p. 173; Zeszyty Naukowe Wyższej Szkoty Oficerskiej MSW w Szczytnie, special issue, No. 7, 1978; T. Hanausek, Poligraf w systemie badań i czynności kryminalistycznych, Problemy Kryminalistyki 1975, No. 118, pp. 650 and ff.; A. Różycki, Uwagi o przydatności wariografu, Problemy Kryminalistyki, No. 54, 1965, p. 340; E. Skrętowicz, Badania wariograficzne w procesie karnym, Nowe Prawo, No. 4, 1965, p. 371; J. Widacki, Badanie poligraficzne i jego wykorzystanie w praktyce niektórych krajów, Krakowskie Studia Prawnicze 1976; S. Waltoś, Warunki zastosowania poligrafu w procesie karnym, Archiwum Medycyny Sądowej i Kryminologii, No. 1, 1974, p. 123.

16. See: J. Widacki, Wartość diagnostyczna badania poligraficznego i jej znaczenie kryminalistyczne, Wydawnictwo UJ, Kraków 1977.

17. T. Hanausek, Nowa oferta kryminalistyki, Zeszyty Naukowe Wyższej Szkoły Oficerskiej MSW w Szczytnie, special issue, No. 7, 1978, p. 16; Z. Sobolewski, Zasada nemo se ipsum accusaretenatur $w$ polskim procesie karnym, Lublin 1979, p. 159; Państwo i Prawo No. 5, 1979, gloss by W. Daszkiewicz and M. Jeż-Ludwichowska, Nowe Prawo No. 7-8, 1979, gloss by S. Waltoś and J. Widacki.

18. A. Krzyścin, Rozwój kryminalistycznych badań poligraficznych w latach 1920-1995, Problemy Kryminalistyki, No. 209, 1995, pp. 21-23.

19. See: A. Krzyścin, Wykorzystanie poligrafu przez agencje rzadowe USA w latach 1964-1984, internal document of the Ministry of the Interior, Warszawa 1984.

20. Ibidem.

21. J. Łabędzki, M. Strużyński, $Z$ doświadczeń pracownika operacyjnego SB. Sprawa kryptonim “Cezary”, Warszawa 1972. 
22. A. Krzyścin, Notatka informacyjna, Rozwój psychofizjologicznych badań poligraficznych w Polsce w latach 1950-1955, Warszawa 1996, p. 1.

23. A. Krzyścin, Wykorzystanie poligrafu przez agencje rządowe USA w latach 1964-1984, Warszawa 1985, p. 1.

24. Z. Broniarek, Gdzie jest dusza R. Reagana, Przegląd Tygodniowy 1986, No. 4.

25. M. Cegielski, Wykorzystanie kryminalistycznej techniki badań poligraficznych przez CIA w stosunku do obywateli polskich w świetle badań akt postępowań przygotowawczych prowadzonych w latach 1970-1984 przez Biuro Śledcze MSW (unpublished diploma work), Wyższa Szkoła Oficerska im. Feliksa Dzierżyńskiego, Legionowo 1986, p. 44.

26. Ibidem, p. 43.

27. Ibidem, pp. 44-48.

28. Ibidem, pp. 106-109.

29. Ibidem, pp. 109-113.

30. Ruling of the Supreme Court from 1964, III K 177/64; Ruling of the Regional Court in Olsztyn from 1963, IV K 94/63.

31. A. Krzyścin, Rozwój badań poligraficznych w latach 1920-1995, Problemy Kryminalistyki 209 (1995), p. 24; A. Krzyścin, The Debate Over Polygraph in Poland, Polygraph 2000, vol. 29, No. 3, p. 226.

32. See: A. Krzyścin, Notatka informacyjna..., p. 2.

33. W. Kuboń, L. Wiśniewski, M. Jóźwiak, Stosowanie wariografu w praktyce, Problemy Kryminalistyki 1976, No. 121-122.

34. Ibidem.

35. Ibidem.

36. J. Bieńkuński, Rola i znaczenie badań poligraficznych..., p. 20.

37. J. Bieńkuński, Rozwój badań poligraficznych (wariograficznych) w sitach zbrojnych RP w latach 1969-1998, p. 18.

38. Ibidem.

39. A. Krzyścin, Badania poligraficzne wykonane technika Reida. Analiza doświadczeń polskich (unpublished doctoral dissertation), Uniwersytet Śląski, Katowice 1980, pp. 218-223. 
40. Z. Knyziak, Wariograf w procesie karnym, Departament Szkolenia i Wydawnictw MSW, Warszawa 1971, pp. 27, 28, 88 and ff.

41. M. Cegielski, op. cit., pp. 54-55.

42. J. Bieńkuński, Rola $i$ znaczenie badań poligraficznych $w$ dziataniach wykrywczych organów ścigania i wymiaru sprawiedliwości, expert study commissioned by the Expert and Studies Centre of the Chancellery of the Polish Parliament of 3 April 1996, Warszawa 1996, p. 5.

43. W. Kuboń, L. Wiśniewski, M. Jóźwiak, Zastosowanie wariografu w praktyce, Problemy Kryminalistyki 1976, No. 121-122, pp. 148 and ff.; J. Widacki, Analiza przestanek diagnostycznych $w$ badaniach poligraficznych, Katowice 1982, p. 7; J. Widacki, Identyfikacja przez badanie śladów emocjonalnych, J. Widacki (ed.), Kryminalistyka, 2nd ed., Warszawa 2002, p. 418.

44. J. Bieńkuński, Rola i znaczenie badań poligraficznych..., p. 5.

45. A. Krzyścin, Badania poligraficzne wykonane technika Reida..., pp. 213-214.

46. See: J. Widacki, A. Feluś, Dziatalność opiniodawcza Zaktadu Kryminalistyki US, Problemy Kryminalistyki 1979, No. 138.

47. J. Bieńkuński, J. Suliński, Rozwój badań poligraficznych (wariograficznych) w Sitach Zbrojnych RP w latach 1969-1998, Warszawa 2002 p. 6; A. Krzyścin, Badania poligraficzne wykonane technika Reida..., pp. 216-218; W. Kuboń, L. Wiśniewski, M. Jóźwiak, Zastosowanie wariografu w praktyce, Kryminalistyki 1976, No. 121-122.

48. Lex 21726. Ruling from 25 September 1976, case file ID: II KR 171/176.

49. A. Krzyścin, Rozwój psychofizjologicznych badań poligraficznych w Polsce, lata 1950-1955 (typescript), Warszawa, February 1996, pp. 5-6; A. Krzyścin, Problematyka wykorzystania poligrafu w procesie karnym (typescript), Warszawa, May 1995, p. 10.

50. A. Krajewska, Konfesjonat $w$ neseserze, Czas 1979, No. (246) 41, 14 October; A. Krzyścin, Badania poligraficzne wykonane technika Reida analiza doświadczeń polskich (unpublished doctoral dissertation), Katowice 1980, pp. 72-73; Głos Wybrzeża, Wielkie ktamstwo wykrywaczy ktamstw, June 1973.

51. See e.g.: Paweł Horoszowski's reference to US News and World Report weekly of 22 March 1957: Od zbrodni do kary, 1st ed., 1963, p. 257.

52. S. Lem, Sezam, [in:] Sezam i inne opowiadania, Warszawa 1954, pp. 123-124.

53. G.A. Złobin, S.A. Jani, Problematika poligrafa, [in:] Problemi soverschenstvovani i sovetskogo zakonodatelstva, Moscow 1976, p. 129 [found in:] J. Widacki, Wprowadzenie do problematyki badań poligraficznych, p. 176. 
54. See e.g.: M. Dufek, K problematyce poligrafickehovy setrovani v kryminalistice, [in:] Doplinkove studijn i materialy pro kryminalistickysmer pravnickeho studia, UK Praha 1970 [found in:] J. Widacki, Wprowadzenie do problematyki badań poligraficznych, p. 176.

55. T. Markovic, Suvremena technika israzivanja krivcnih djela, Zagreb 1972, p. 527; Z. Aleksic, Naucno otkrivanje zlocina, Beograd 1972, pp. 308-310 [found in:] J. Widacki, Wprowadzenie do problematyki badań poligraficznych, pp. 172-173. 